\title{
INTERACTIVE CONTROL SYSTEM, INTENDED STRATEGY, IMPLEMENTED STRATEGY DAN EMERGENT STRATEGY
}

\author{
Tubagus Ismail $^{1}$; Darjat Sudrajat ${ }^{2}$ \\ ${ }^{1}$ Jurusan Akuntansi FE Universitas Sultan Ageng Tirtayasa \\ Jl. Jakarta KM 4 Serang Banten, Serang, Banten 42119, Indonesia \\ ${ }^{2}$ Management Department, School of Business Management, Binus University \\ Jl. K.H. Syahdan No. 9, Palmerah, Jakarta Barat 11480 \\ sudrajat.darjat@yahoo.com
}

\begin{abstract}
The purpose of this study was to examine the relationship between management control system (MCS) and strategy formation processes, namely: intended strategy, emergent strategy and impelemented strategy. The focus of MCS in this study was interactive control system. The study was based on Structural Equation Modeling (SEM) as its multivariate analyses instrument. The samples were upper middle managers of manufacturing company in Banten Province, DKI Jakarta Province and West Java Province. AMOS Software 16 program is used as an additional instrument to resolve the problem in SEM modeling. The study found that interactive control system brought a positive and significant influence on Intended strategy; interactive control system brought a positive and significant influence on implemented strategy; interactive control system brought a positive and significant influence on emergent strategy. The limitation of this study is that our empirical model only used one way relationship between the process of strategy formation and interactive control system.
\end{abstract}

Keywords: interactive control system, intended strategy, emergent strategy and manufacture

\begin{abstract}
ABSTRAK
Penelitian ini bertujuan untuk meneliti hubungan management control system (MCS) dengan proses pembentukan strategi berupa intended strategy, emergent strategy serta implemented strategy. Fokus MCS yang digunakan dalam penelitian ini adalah interactive control system. Penelitian ini menggunakan structural equation modeling (SEM) sebagai alat analisis multivariate. Sampel yang digunakan adalah pimpinan menengah dan puncak perusahaan manufaktur yang terdapat di Propinsi Banten, DKI Jakarta dan Jawa Barat. Software AMOS 16 digunakan sebagai alat bantu untuk memecahkan permasalahan SEM. Penelitian ini menemukan bahwa interactive control system berpengaruh positif dan signifikan terhadap intended strategy; interactive control system berpengaruh positif dan signifikan terhadap implemented strategy; interactive control system berpengaruh positif dan signifikan terhadap emergent strategy Keterbatasan penelitian ini adalah model empiris dalam penelitian ini hanya menggunakan hubungan satu arah antara proses strategi dan MCS.
\end{abstract}

Kata kunci: interactive control system, intended strategy, emergent strategy, manufaktur 


\section{PENDAHULUAN}

Strategi perusahaan sering berasal dari sebuah proses perencanaan yang terorganisir dan ketat. Namun strategi yang telah mendorong organisasi ke puncak industri tidak jarang berasal dari strategistrategi yang dilakukan melalui trial and error dan menjadi keberhasilan yang tak terduga. Jarang sekali strategi yang memenangkan persaingan bisnis berasal dari strategi yang telah ditetapkan diawal. Organisasi bisnis digambarkan seperti menyelam kedalam perairan ekonomi yang tidak menentu, sehingga sangat penting bagi para pemimpin perusahaan memahami proses terbentuknya strategi, untuk menuntun mereka mencapai tujuannya secara efektif.

Agar suatu bisnis tetap bertahan dan maju, management control system dibuat secara eksplisit untuk mendukung strategi (Dent, 1990). Pada dasarnya tujuan dari management control system (MCS) adalah untuk memberikan informasi yang berguna dalam proses pengambilan keputusan, perencanaan dan evaluasi (Merchant dan Otley, 2006). MCS merupakan alat untuk menciptakan kerja sama baik secara kolektif maupun individual unit organisasi dan menjadi saluran bagi berbagai upaya dan usaha yang dilakukan untuk mencapai tujuan spesifik suatu perusahaan (Ouchi, 1979; Flamholtz, 1983).

Sejauh ini, banyak literatur dalam yang telah menelaah efek dari strategi terhadap MCS (Dent, 1990; Langfield-Smith, 1997; Henri, 2006). Akan tetapi riset yang menekankan efek dari MCS terhadap strategi, konsep strategi paling banyak diteliti pada tingkatan pilihan strategi sedangkan pada proses pembentukan strategi masih sedikit (Kober et al., 2007).

Beragam peneliti sudah menjelaskan bahwa hasil temuan yang diberikan oleh alur MCS strategi dari sudut penelitian masih bersifat ambigu dan kadangkala bertentangan (Abernethy \& Brownell, 1999; Ittner dkk, 2003; Langfield-Smith, 1997). Hasil yang bersifat ambigu ini dikarenakan beragam definisi yang ada, konseptulisasi dan operasionalisasi dari strategi dan MCS (Kald et al., 2000; Langfield-Smith, 1997; Simons, 1990). Hal ini juga dapat dijelaskan oleh dua alasan. Pertama, hubungan yang terjadi antara MCS dan strategi mungkin tidak diteliti dengan tingkat analisa yang tepat. Seperti dijelaskan oleh Ittner dan Larcker (2001) salah satu elemen kunci dalam mempelajari MCS dan strategi adalah dengan mengidentifikasi faktor spesifik yang mengarah pada terbentuknya strategi. Dan kedua, sedikitnya perhatian yang diberikan pada masalah proses pembentukan strategi yang muncul akibat penggunaan MCS (Kober et al., 2007).

Hanya ada dua riset yang menekankan pada efek dari penggunaan MCS terhadap strategi yang mengkonsepkan strategi sebagai pendekatan proses (Roberts, 1990; Kober et al, 2007). Roberts (1990) dan Kober et al., (2007) menemukan bahwa MCS akan memfasilitasi strategi yang terdapat pada perusahaan. Secara spesifik penggunaan MCS secara interactive berpengaruh positif terhadap proses pembentukan startegi.

Para peneliti yang menyelidiki hubungan MCS dan proses pembentukan strategi telah mengkonsepkan proses pembentukan strategi dengan menjadi dua bagian (Chenhall, 2005). Pertama, emergent strategy, muncul dari proses atau perkembangan jalannya suatu strategi serta memiliki respon yang cepat terhadap perubahan yang mendadak. Kedua, intended strategy, merupakan strategi yang dirumuskan diawal oleh top manajemen, yang dapat saja tidak terpakai jika ada perubahan yang tidak terduga.

Meskipun peneliti terdahulu telah meneliti hubungan antara penggunaan interactive control system dan proses pembentukan strategi (Roberts, 1990; Kober et al., 2007), hasil penelitian tersebut belum memberikan hasil yang dapat digeneralisasi. Penelitian yang dilakukan oleh Roberts (1990) dan Kober et al. (2007) dan menggunakan metode kualitatif studi kasus. Penelitian studi kasus memungkinkan analisis yang lebih mendetil dari sebuah proses perubahan strategi dan penggunaan 
pendekatan studi kasus banyak didukung oleh para peneliti (Dent, 1990). Namun, kemampuan generalisasi dari hasil temuan ini masih terbatas karena adanya beragam karakteristik organisasi yang bersifat spesifik. Penelitian ini menjelaskan hubungan kausal antara interactive control system dan proses pembentukan dan implemented strategy dengan metode kuantitatif, sehingga hasilnya lebih dapat digeneralisasi.

\section{Teori dan Definisi Konstruk}

\section{Interactive Control System}

Interactive control system adalah sebuah sistem formal yang digunakan oleh manajer puncak sebuah perusahaan untuk melibatkan dirinya secara teratur dan secara personal pada aktivitas pengambilan keputusan dari pihak bawahan (Simons, 1987; Simons, 1994 ; Simons, 1995; Simons, 2000). Interactive control system digunakan untuk merangsang dialog, tatap muka dan untuk membangun jembatan informasi antar tingkatan hirarkis, departemen fungsional dan pusat laba. Sistem pengendalian diagnostik dapat dibuat bersifat interaktif dengan cara melanjutkan dan secara terus menerus memberikan perhatian dan minat pada pihak manajemen. Interactive control system digunakan oleh manajemen puncak untuk memandu proses pembentukan strategi secara informal dengan menetapkan kerterlibatan pribadi, intimasi atau kedekatan dengan permasalahan, dan komitmen (Mintzberg, 1987).

Sebuah sistem akan diklasifikasikan sebagai sistem yang interaktif jika manajer puncak melaporkan bahwa sistem tersebut sering digunakan secara personal, teratur dan menjadi prioritas baik bagi dirinya sendiri maupun bagi bawahannya (Simons, 1990). Sistem ini digunakan pada pertemuan rutin yang dilakukan secara langsung baik dengan bawahan maupun dengan pihak lain untuk meninjau data dan menghasilkan rencana tindakan (Simons, 1990).

Interactive control system bukan merupakan tipe unik dari sistem pengendalian (Simons, 1994; Simons, 2000). Setiap sistem pengendalian dapat digunakan secara interaktif oleh senior manajer jika sistem tersebut cocok dengan tingkat ketidakpastian yang disyaratkan (Simons, 2000;219). Sedangkan pemilihan terhadap interactive control system sangat tergantung pada empat faktor yaitu 1) ketergantungan teknologi, 2) regulasi, 3) kompleksitas penciptaan nilai, dan 4) kenyataan dari respon taktis (Simons, 2000). Terdapat beberapa alasan manajer menggunakan interactive control system, yaitu 1) ekonomi, perhatian manajemen merupakan sumber daya yang langka dan mahal; 2) kognitif, kemampuan setiap individu untuk memproses informasi dalam jumlah besar bersifat terbatas; dan 3) stratejik, berkaitan dengan pembelajaran aktif mengenai ketidakpastian strategi dan mengumpulkan rencana tindakan baru (Simons, 2000).

Manajer puncak harus memutuskan aspek mana dari sistem pengendalian manajemen yang akan digunakan secara interaktif dan aspek mana yang menjadi programnya (Simons, 1987). Pengendalian manajemen menjadi bentuk pengendalian yang bersifat interaktif ketika manajer menggunakan prosedur perencanaan dan pengendalian yang secara aktif memonitor dan melakukan intervensi pada pihak bawahan atas akivitas pengambilan keputusan yang sifatnya terjadi secara terus menerus (Simons, 1990). Karena intervensi yang dilakukan akan memberikan peluang bagi tim manajemen puncak untuk memperdebatkan dan menantang berdasarkan data dasar dan rencana tindakan lainnya. Oleh karena itu pengendalian interaktif menuntut perhatian yang terus menerus dari pihak bawahan yang beroperasi di semua tingkatan perusahaan (Simons, 1990).

Perusahaan modern memiliki jenis dan bentuk sistem pengendalian yang berbeda. Manajer puncak akan memilih untuk membuat sistem pengendalian manajemen yang sifatnya interaktif jika sistem yang ada mengindikasikan adanya ketidakpastian strategi. Sistem interaktif terpilih dapat digunakan oleh manajer puncak untuk dua fungsi berikut: pemberian tanda atau sinyal dan tindakan observasi atau pengawasan terhadap keputusan yang telah diambil (Simons, 1990). 
Pemberian tanda atau sinyal adalah penggunaan informasi yang ada untuk mengungkapkan adanya preferensi. Pemberian tanda atau sinyal sangat penting karena manajer puncak tidak dapat selalu mengetahui kapan atau dimana momentum untuk pengambilan keputusan penting, bagaimana atau mengapa sebuah keputusan akan dibuat, atau untuk siapa keputusan tersebut dibuat. Proses pengambilan keputusan ini akan mengalami difusi saat input diterima dari beragam pelaku dan dalam periode waktu yang panjang.

Dengan menggunakan interactive control system yang berfungsi untuk mengawasi atau memonitor ketidakpastian strategis, manajemen puncak akan cendrung lebih memilih kepada individu yang memberikan masukan terhadap proses pengambilan keputusan. Tindakan obervasi atau pengawasan adalah tindakan untuk mencari hal-hal yang terjadi di luar dugaan, pengendalian manajemen interaktif akan memberikan panduan terhadap anggota organisasi dimana mencari hal yang diluar dugaan tersebut dan jenis informasi apa yang akan dikumpulkan (Simons, 1990). Hal yang terjadi diluar dugaan ini kemungkinan bisa saja menjadi alternatif baru, preferensi baru atau perubahan bagi perusahaan (Feldman dan March, 1981). Pilihan berbagai alternatif baru yang ditawarkan kepada manajer puncak sangat diperlukan saat keputusan tersebut berkaitan dengan kebijakan strategis dan sumber daya yang dimilikinya (Mintzberg, 1973b, p. 87; Bower, 1986, hal. 64). Interactive control system mengendalikan dan memungkinkan manajer puncak untuk memiliki informasi penuh atas alternatif keputusan yang akan diambil dan didistribusikan ke seluruh lini perusahaan.

\section{Proses Pembentukan Strategi dan Implementasi Strategi}

Para peneliti manajemen strategi telah menyelidiki perubahan cara strategi dikonsepkan dan menelaah hubungan antara strategi dan SPM sejak pertengahan tahun 1990an (Langfield-Smith, 2007). Proses saat strategi terbentuk dan diimplementasikan telah menarik perhatian banyak pihak untuk menelitinya. Bhimani dan Langfield-Smith (2007. hal. 3-4) menyatakan bahwa literatur yang membahas manajemen strategi memberikan indikasi adanya keragaman yang sangat tinggi dalam hal bentuk dan sifat alamiah dari suatu proses strategi yang terjadi dalam suatu organisasi. Karakterisasi yang beragam proses strategi telah banyak dikemukakan dan dijelaskan oleh para peneliti (Johnson dan Scholes, 1999).

Salah satu bentuk karakteristik dari proses pembentukan strategi dalam taksonomi yang berkembang saat ini dijelaskan dengan rinci oleh Mintzberg (1978, 1987, 1994); Mintzberg dan Waters (1985); Mintzberg dan McHugh, 1985); dan Mintzberg (1990, 1994). Terdapat dua proses yang independen dan bekerja secara simultan dalam proses pembentukan strategi (Mintzberg dan Waters, 1985). Pertama, intended strategy, dalam taksonominya, strategi dipandang sebagai suatu pernyataan yang bertujuan proaktif dan berbentuk formal serta telah direncanakan sebelum suatu keputusan diambil atau suatu tindakan dilakukan. Setelah proses pembentukan strategi selesai selanjutnya akan diikuti dengan tahap implementasi (Langfield-Smith, 1997). Strategi semacam ini dinyatakan sebagai intended strategy. Intended strategy adalah sebuah rencana yang menjadi tujuan perusahaan dan diperkirakan sebagai tindakan yang paling sesuai untuk mencapai tujuan perusahaan (Mintzberg, 1978). Jika situasi yang ada dianggap sudah sesuai dengan keinginan, maka manuver atau trik dan hal semacamnya akan dapat digunakan untuk menghambat/mengancam perusahaan pesaing (Mintzberg, 1978). Konsep dasar dari strategi ini adalah bahwa seluruh tindakan harus direncanakan terlebih dahulu. Dalam hal ini, intended strategy menjelaskan adanya rencana dari posisi puncak ke posisi bawah.

Intended strategy dapat diimplementasikan jika tiga persyaratan berikut terpenuhi (Mintzberg and Water, 1985). Pertama, orang-orang yang ada dalam organisasi harus memahami setiap detil penting apa yang dimaksudkan manajemen dalam indended strategy. Kedua, setiap anggota organisasi harus melihat dunia bisnis ini sebagai tindakan yang kolektif. Ketiga, perhatian kolektif ini dapat diwujudkan jika hal-hal yang tidak terduga seperti politik, teknologi atau kekuatan pasar tidak terlalu 
berpengaruh. Ketiga ketentuan ini sangat sulit ditemukan, sehingga sangat jarang intended strategy dapat dilaksanakan tanpa perubahan yang signifikan (Mintzberg and Water, 1985).

Proses pembentukan strategi kedua disebut emergent strategy. Strategi ini adalah akibat dari pengaruh kumulatif dari keputusan sehari-hari yang dibuat oleh manajer menengah, insinyur, tenaga penjualan dan keuangan. Keputusan yang dibuat oleh mereka biasanya memiliki karakter yang taktis, tidak dibingkai sebagai keputusan strategis sama sekali. Emergent strategy adalah strategi yang kemunculannya untuk memberikan tanggapan atau respon terhadap adanya ancaman eksternal yang tidak diprediksi sebelumnya atau tidak diduga sebelumnya melalui uji coba atau trial dan error (Mintzberg, 1994). Strategi ini muncul dari aktivitas sehari-hari suatu bisnis dan seringkali berasal dari ide atau gagasan yang muncul dari posisi bawah ke pihak atasan yang sifatnya tidak terduga. Sebagai contoh, untuk memudahkan pengelolaan, Sam Walton pemilik WallMart, memutuskan membangun toko kedua di kota kecil, dekat dengan toko yang pertama di Bentonville, Arkansas. Hal ini menyebabkan penemuan ekonomi yang menarik, ada bangunan toko yang besar di kota kecil. Emergent strategy hasil dari respon sehari-hari manajer untuk masalah atau kesempatan yang tak terduga oleh mereka yang terlibat dalam proses pembuatan intended strategy pada saat top manajemen melakukan analisis dan perencanaan.

Taksonomi tentang intended strategy ataupun taksonomi emergent strategy tidak hanya dilihat dari cara pembentukan strategi tersebut dikonsepkan, namun para peneliti telah menguatkan model penelitian mereka yang membahas mengenai bagaimana suatu strategi dibentuk (Chenhall, 2005). Para peneliti dibidang hubungan antara strategi dan SPM yang ada pada saat ini telah mengkonsepkan proses pembentukan strategi dengan membedakan antara intended strategy atau emergent strategy (Chenhall, 2005).

Perspektif yang diambil untuk mendefinisikan impelementasi strategi sangat beragam. Hal ini meliputi tindakan pengendalian, monitoring dan evaluasi (Hrebiniak and Joyce, 1985), pelaksanaan dari rencana strategi (Floyd dan Woolridge, 1992), alokasi sumber daya, pemecahan masalah-masalah operasional (Cespedes, 1991; Laffan, 1983), mengubah tujuan strategi menjadi suatu rencana operasional dan menjelaskan strategi yang telah dipilih menjadi suatu tindakan yang nyata (Johnson dan Scholes, 1999). Sudut pandang semacam ini sangat terbatas sehingga para peneliti tidak berhasil mengenali bentuk alamiah dari strategi yang sifatnya emergent dari proses implementasi, dimana pembentukan strategi pada tahapan awal akan berubah karena adanya perubahan kondisi lingkungan ataupun kondisi organisasional.

Sedikit sekali literatur yang membahas model konseptual implemented strategy yang mengakomodasi bentuk alamiah strategi yang sifatnya emergent atau intended, khususnya jika dikaitkan dengan akuntansi manajemen. Namun demikian ada dua studi yang memberikan panduan pada penelitian ini tentang bagaimana konstruk implemented strategy akan dilihat dalam studi ini. Noble (1999) melakukan tinjauan terhadap lima puluh konsep dan studi yang berhubungan dengan implemented strategy. Noble (1999) menemukan bahwa kemampuan untuk menyesuaikan kebudayaan, struktur dan kekerapan munculnya gaya manajemen dalam suatu organisasi akan memberikan pengaruh yang besar terhadap proses implementasi strategi.

Dalam suatu studi kasus yang mengidentifikasi keberhasilan implementasi strategi yang menjadi tujuan pada sebuah perusahan kapal pesiar di Norwegia, Heide et al. (2002) menemukan bahwa terdapat tujuh aspek dari implementasi strategi yang mendapatkan perhatian khusus pada literatur saat ini. Empat dari tujuh aspek yang ada ini dinyatakan memiliki nilai penting dan khusus yaitu: (1) keterlibatan awal para anggota sebuah organisasi terhadap proses implementasi strategi, (2) pemberian infomasi tentang strategi yang sifatnya relevan dengan pegawai dalam seluruh lini perusahaan melalui mekanisme komunikasi yang bersifat vertikal ataupun horizontal; (3) memberikan ilmu pengetahuan dan keterampilan yang sangat penting untuk mengimplementasikan suatu strategi terhadap seluruh pegawai yang terdapat dalam perusahaan; dan (4) mengalokasikan dana serta sumber 
daya manusia yang memadai dan mampu untuk mengimplementasikan sebuah strategi. Hasil temuan yang diperoleh dari dua studi ini memberikan indikasi adanya faktor-faktor yang sangat berpengaruh dalam implementasi strategi.

\section{Pengukuran Konstruk}

Pengukuran konstruk interactive control system menggunakan indicator yang dikembangkan oleh Simons (1995), Henri (2006) yaitu : Mengembangkan diskusi dalam rapat dengan atasan, bawahan dan rekan (ics1) ; Mengembangkan tantangan dan perdebatan berdasarkan data, asumsi dan rencana tindakan (ics2); Memberikan pandangan umum organisasi (ics3); Komitmen pada organisasi (ics4); Fokus pada masalah utama (ics5); Fokus pada faktor sukses (ics6); Mengembangkan bahasa yang umum di organisasi (ics7). Strategi dengan pendekatan proses disini terdiri dari pertama, intended strategy, indicator yang digunakan untuk mengukur konstruk ini diadopsi dari hasil kerja Boyd dan Reuning-Elliot (1998) yaitu : Mission statements (ins8); Trend analysis (ins9) ; Competitor analysis (ins10) ; Longterm goal (ins11); Annual goals (ins12); Action plans (ins13); On going evaluation (ins14). Kedua, emergent strategy. Indikator yang digunakan untuk mengukur konstruk emergent strategy dikembangkan dari hasil kerja Mintzberg dan Waters (1985) dan Marginson (1999) yaitu : Strategi yang oportunis (es15); Bottom up strategy (es16); Strategi intuisi (es17). Pengukuran kosntruk implementasi strategi diambil dari hasil kerja Noble (1999) dan Heide, et al. (2002) yaitu : Keterlibatan seluruh anggota (ims18), Penyesuaian struktur organisasi (ims19), Penyesuaian gaya manajemen (ims20), Penyesuaian budaya organisasi (ims21), Tersedianya informasi pada seluruh organisasi (ims22), Tersedianya pengetahuan dan keterampilan pegawai (ims23) dan Pengalokasian dana dan sumber daya (ims24)

\section{Pengembangan Hipotesis}

Sesuai dengan temuan dari Mintzberg (1978) membedakan antara intended strategy yang merupakan strategi yang telah menjadi tujuan dan emergent strategy yang merupakan strategi yang bersifat spontan yang mungkin akan terbentuk. Sudut pandang konvensional dari hubungan antara MCS dan strategi menyatakan bahwa penggunaan MCS akan memberikan pengaruh pada pembentukan strategi (Merchant dan Otley, 2006).

Konsep pembentukan strategy yang terdiri dari intended strategy dan emergent strategy serta implementasi strategi (Mintzberg, 1978, 1987, 1994; Mintzberg dan Waters, 1985) disatukan dengan hasil kerja Simons $(1990,1991,1994,1995)$ yang meneliti penggunaan pengendalian interaktif. Simons (1990, 1991, 1994, 1995) memberikan dukungan teoretis dan empiris bagaimaan cara penggunaan sistem pengendalian interaktif (interactive control systems). Interactive control systems membantu organisasi untuk mengkomunikasikan agenda strategis dan mengarahkan perhatian organisasi terhadap ketidakpastian yang mungkin muncul untuk pembentukan strategi. Simons (1995) meneliti bahwa interactive control systems akan mendukung munculnya dialog dan perdebatan yang akan berlangsung dalam waktu yang cukup lama. Interactive control systems juga menciptakan tekanan yang sifatnya kompetitif dalam suatu organisasi untuk melakukan inovasi dan adaptasi (Simons, 1995). Oleh karena itu interactive control systems akan berepengaruh positif terhadap intended strategy yang telah terencana dari awal dan emergent strategy yang sifatnya spontan.

Perubahan dalam hubungan tradisional yang terjadi antara MCS dan pembentukan strategi sudah dipertegas oleh peneliti lainnya yang menelaah hubungan MCS dan strategi. Marginson (2002) menemukan bahwa persepsi manajerial akan pengunaan MCS akan berepngaruh positif dengan pembentukan dan implementasi strategi. Artinya, intended strategy, emergent strategy dan implemented strategy akan dipengaruhi MCS. Kober et al. (2007) menemukan bahwa mekanisme MCS yang digunakan dengan cara interaktif akan membantu untuk memfasilitasi pembentukan dan implementasi suatu strategi. Uraian tersebut mengarah pada terbentuknya hipotesa sebagai berikut :

H1: interactive control system berpengaruh positif terhadap intended strategy. 
$\mathrm{H} 2$ : interactive control system berpengaruh positif terhadap implemented strategy.

$\mathrm{H} 3$ : interactive control system berpengaruh positif terhadap emergent strategy.

\section{METODE}

\section{Sampel dan Prosedur Pengumpulan Data}

Unit analisis dalam penelitian ini adalah pimpinan menengah ke atas yang ada di perusahaan manufaktur di Provinsi Banten, DKI Jakarta dan Jawa Barat. Berdasarkan pertimbangan data manajer unit bisnis dari perusahaan manufaktur tidak tersedia, maka metode pemilihan sampel yang digunakan dalam penelitian ini adalah metode pemilihan sampel bertujuan (purposive sampling). Alasan menggunakan metode purposive sampling dalam penelitian ini adalah agar peneliti benar-benar mendapatkan informasi yang dibutuhkan dari objek yang tepat.

Pertimbangan atau kriteria penentuan sampel dalam penelitian ini adalah sebagai berikut: (1) pimpinan menengah ke atas perusahaan manufaktur yang berada di Propinsi Banten, DKI Jakarta dan Jawa Barat. Adapun alasannya adalah karena $60 \%$ industri manufaktur terletak di tiga propinsi tersebut; (2) pimpinan menengah ke atas yang memiliki kriteria berikut : manajer tersebut paling kurang memiliki pengalaman selama dua tahun di perusahaan tersebut, dengan begitu mereka diharapkan memiliki pengetahuan mengenai masalah-masalah yang berkaitan dengan strategis; (3) pimpinan menengah ke atas perusahaan yang bergerak pada industri manufaktur yang bertipe prospector. Hal ini dikarenakan pada industri-manufaktur yang prospector, perusahaan aktif mencari peluang dengan inovasi yang terus menerus, berperilaku sangat kreatif, memilki kreativitas yang tinggi dan daya inovasi yang besar. Orang-orang yang bekerja pada perusahaan dengan tipe prospector biasanya memiliki tingkat pembelajaran yang tinggi, memiliki kemampuan bereksplorasi melakukan uji coba strategi yang sangat tinggi.

\section{Jenis dan Prosedur Pengumpulan Data}

Data untuk penelitian ini adalah data primer dalam bentuk persepsi responden dikumpulkan dengan metode diantar langsung kepada responden. Ringkasan jumlah pengiriman dan pengembalian kuesioner pada masing-masing daerah dalam penelitian ini dapat dilihat pada Tabel 1.

Tabel 1 Pengiriman dan Pengembalian Kuesioner

\begin{tabular}{lr}
\hline Keterangan & Total \\
\hline Total kuesioner yang dikirim & 429 \\
\hline Kuesioner yang tidak bisa diambil & 113 \\
\hline Total kuesioner yang kembali & 316 \\
\hline $\begin{array}{l}\text { Kuesioner yang tidak digunakan (bukan responden yang } \\
\text { dimaksud) }\end{array}$ & \\
\hline Total kuesioner yang digunakan & 29 \\
\hline Tingkat pengembalian (response rate) (316/429 x 100\%) & 287 \\
\hline Tingkat pengembalian yang digunakan (usable response rate) & 0.7365967 \\
\hline \begin{tabular}{l}
$(287 / 429 \times 100 \%)$ \\
\hline
\end{tabular}
\end{tabular}


Total kuesioner yang dikirimkan sebanyak 429, ada 113 reponden yang tidak kembali, karena jadwal kerja yang padat responden sulit ditemui. Dari 316 kuesioner ada 29 kuesioner tidak bisa digunakan karena kuesioner di isi oleh responden yang memiliki jabatan pimpinan bawah, bukan pimpinan menengah ke atas perusahaan seperti yang diminta dalam penelititan ini. Sehingga kuesioner yang dapat digunakan dalam analisis data sebanyak 287 kuesioner (429-113-29). Dengan kata lain tingkat pengembanalian kuesioner sebesar $74 \%$ dan tingkat pengembalian yang digunakan sebesar $66.9 \%$.

\section{Structural Equation Model}

Penelitian ini menggunakan structural equation modeling sebagai alat analisis multivariate yang memungkinkan peneliti untuk menguji hubungan antara variabel yang kompleks dan memperoleh gambaran yang menyeluruh mengenai keseluruhan model. SEM telah dianggap sebagai suatu alat statistik yang sangat berguna bagi para peneliti pada seluruh bidang ilmu sosial. SEM telah menjadi suatu keharusan untuk penelitian non eksperimental, dimana metode untuk pengujian teori belum dikembangkan secara menyeluruh. Penelitian ini menggunakan software AMOS 16 sebagai alat bantu untuk memecahkan permasalahan SEM.

Pada analisis confirmatory factor analysis konstruk exogen dan endogen dengan mengkorelasikan masaing antar konstruk exogen dan endogen, tampak bahwa konstruk interactive control system harus dimodifikasi dengan mengeluarkan loading indikator yang dibawah 0.5 yaitu: ics3, ics5 dan ics6. Sementara itu konstruk intended strategy, emergent strategy dan implemented strategy harus dimodifikasi dengan menghilangkan beberapa indikator yang memiliki nilai loading di bawah 0.5 yaitu ins8, ins 10, ins12, ims19, ims22 dan ims23. Oleh karena itu, enam indikator tersebut harus dikeluarkan dari model. Setelah dilakukan modifikasi berdasarkan CFA exogen dan endogen, model dengan indikator yang ada di run kembali, sehingga menghasilkan output AMOS seperti pada Gambar 1.

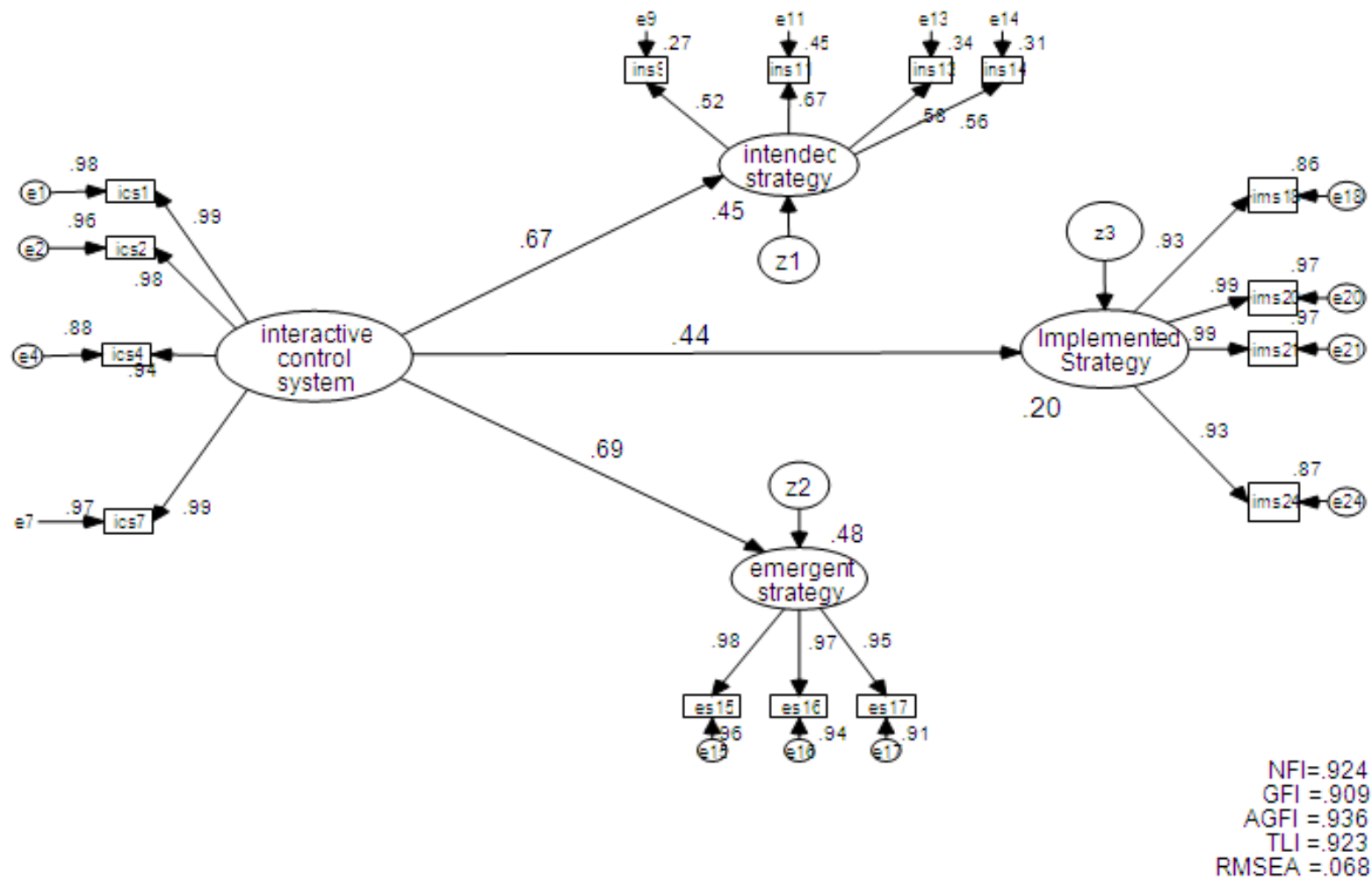

Gambar 1 Output full model 


\section{HASIL DAN PEMBAHASAN}

\section{Pengujian Asumsi Model Penelitian}

\section{Pengujian Normalitas Data}

Pengujian normalitas data dilakukan dengan menggunakan kriteria nilai kritis sebesar $\pm 2,58$ pada tingkat signifikan 0,01 . Apabila nilai kritis dari hasil penelitian ini lebih besar dari kriteria nilai kritis tersebut, maka dapat diduga bahwa distribusi data adalah tidak normal. Hasil Structural Equation Modeling bagian assessment of normality, pada kolom critical ratio (C.R.) secara multivariate adalah sebesar 1.81 berarti lebih besar dari $\pm 2,58$. Dengan demikian, hasil pengujian normalitas untuk data penelitian ini telah memenuhi syarat untuk dikategorikan sebagai normal secara multivariate.

\section{Pengujian Outliers}

Evaluasi multivariate outliers dilakukan dengan menggunakan perhitungan jarak mahalanobis (the mahalonobis distance) untuk tiap-tiap variabel. The mahalonobis distance menunjukkan jarak sebuah variabel dari rata-rata semua variabel dalam sebuah ruang multidimensional (Ferdinand, 2005). Perhitungan jarak mahalanobis didasarkan pada nilai chi-square dalam tabel distribusi $\chi^{2}$ pada derajat bebas sebesar jumlah variabel yang digunakan dalam penelitian. Dalam penelitian ini digunakan 24 variabel pada tingkat $\mathrm{p}<0,001$ yaitu $\chi^{2}(24 ; 0,001)=40,79$. Oleh karena itu, data yang memiliki jarak mahalanobis lebih besar dari 40,79 dianggap multivariate outliers. Dalam data penelitian ini tidak ada jarak mahalanobis nilainya di atas 40,79 .

\section{Pengujian Multicollinearity}

Untuk melihat apakah terdapat multicollinearity atau singularity dalam sebuah kombinasi variabel, perlu mengamati determinan matriks kovarians. Program AMOS 16.0 akan secara otomatis memberikan warning bila matriks kovariansnya bersifat singular. Indikasi multicollinearity dapat dilihat jika nilai korelasi antar konstruk $>1$ (Byrne, 2010). Karena dalam analisis ini tidak ada warning dan tidak terdapat nilai korelasi antar konstruk $>1$ maka matriks kovarians ini adalah nonsingular dan karena itu dapat dianalisis.

\section{Pengujian Kelayakan Model Penelitian}

Dari Gambar 1 dapat dilihat bahwa goodness of fit menunjukkan model fit yang cukup baik. Dengan nilai RMSEA pada $0.068<0.08$, AGFI sebesar $0.936>0.9$, komponen evalausi TLI pada 0.923 , CFI pada 0.980, NFI pada 0.924 dan GFI sebesar 0.909 , secara keseluruhan kriteria tersebut menunjukkan tingkat penerimaan yang baik (fit). Solimun (2006) menyatakan bahwa jika terdapat satu atau dua kriteria goodness of fit yang telah memenuhi, model dikatakan baik.

\section{Pengujian dan Pembahasan Hipotesis}

Setelah perhitungan melalui analisis konfirmasi dan uji structural equation model yang mencakup konstruk intended strategy, emergent strategy, interacitve control system, tahap selanjutnya adalah menguji hipotesis yang diajukan, hasil ujinya dapat dilihat berdasarkam besarnya Critical Ratio dan probabilitas pada output regression weight pada Tabel 2 . 


\begin{tabular}{lrrrrr}
\hline & & & Std. Estimate & S.E. & P \\
\hline intended_strategy & $<---$ & interactive_control_system & .667 & .040 & $* * *$ \\
emergent_strategy & $<---$ & interactive_control_system & .694 & .038 & $* * *$ \\
Implemented_Strategy & $<---$ & interactive_control_system & .444 & .051 & $* * *$ \\
\hline
\end{tabular}

Hipotesis 1 menyatakan bahwa interactive control system berpengaruh positif terhadap intended strategy. Hasil uji terhadap parameter estimasi antara interactive control system dengan intended strategy menunjukkan ada pengaruh yang signifikan dengan nilai loading sebesar 0.667 pada tingkat signifikan sebesar 0.001 (1\%). Dengan demikian, hipotesis 1 diterima. Hal ini sesuai dengan teori kontinjensi (Merchant dan Otley, 2006) yaitu MCS perlu disesuaikan dengan strategi organisasi. Dengan kata lain hasil pengujian secara empiris terhadap hipotesis 1 di atas sejalan dengan temuan hasil studi Kober et al (2007), Roberts (1999) dan Marginson (2002) bahwa pembentukan strategi yang terdiri dari intended strategy dan emergent strategy (Mintzberg, 1978; Chenhall, 2005) akan diikuti oleh penggunaan MCS secara interaktif.

Hipotesis 2 menyatakan bahwa interactive control system berpengaruh positif terhadap implemented strategy. Hasil uji terhadap parameter estimasi (regression weight) antara interactive control system dengan implemented strategy menunjukkan ada pengaruh positif dengan nilai loadng sebesar 0.444 pada tingkat signifikan sebesar 0.001 (1\%). Dengan demikian hipotesis 2 dapat diterima. Hal ini sesuai dengan teori kontinjensi Merchant dan Otley (2006) bahwa MCS akan menyesuaikan diri dengan strategi yang ada.

Hipotesis 3 menyatakan bahwa interactive control system berpengaruh positif terhadap emergent strategy. Hasil uji terhadap parameter estimasi (regression weight) antara interactive control system dengan implemented strategy menunjukkan ada pengaruh positif dengan nilai loadng sebesar 0.694 pada tingkat signifikan sebesar 0.001 (1\%). Dengan demikian hipotesis 3 dapat diterima. Hal ini sesuai dengan teori kontinjensi Merchant dan Otley (2006) bahwa MCS akan menyesuaikan diri dengan strategi yang ada. Temuan ini mengungkapkan bahwa emergent strategy yang sifatnya spontan membutuhkan pengendalian yang mendukung munculnya dialog dan perdebatan yang berlangsung dalam waktu yang cukup lama. Dialog dan perdebatan tersebut merupakan bagian dari penggunaan MCS secara interaktif. Temuan empiris terhadap hipotesis 3 di atas sesuai dengan hasil studi Kober et al (2007) yang menyatakan bahwa proses emergent strategy akan dipengaruhi oleh mekanisme penggunaan MCS. Lebih spesifik penggunaan MCS yang dimaksud di sini adalah interactive control system.

\section{SIMPULAN}

Hasil pengujian hipotesis 1, hipotesis 2 dan hipotesis 3 menunjukan bahwa intended strategy, implemented strategy dan emergent strategy berpengaruh positif dan signifikan terhadap interactive control system. Ketiga temuan tersebut seusai hasil kerja Menurut Merchant dan Otley (2006) MCS dipengaruhi oleh konteks dimana MCS beroperasi dan perlu disesuaikan dengan kebutuhan dan keadaan organisasi. Salah saru variabel yang berpengaruh dalam menentukan sistem pengendalian manajemen adalah strategi perusahaan (2006)

Model empiris dalam penelitian ini hanya menggunakan hubungan satu arah antara proses strategi dan MCS. Hasil penelitian kualitatif yang dilakukan oleh Kober et al. (2007) dan Roberts 
(1990), menunjukan bahwa hubungan yang terjadi antara strategi dan MCS merupakan hubungan dua arah (timbal balik) yang saling mempengaruhi. Dengan demikian, keterbatasan penelitian ini memberi peluang bagi penelitian kuantitatif yang akan datang untuk mempertimbangkan hubungan timbal balik antara strategi dan MCS.

\section{DAFTAR PUSTAKA}

Abernethy, M. A. dan Brownell, P. (1999). Management control systems in research and development organizations: the role of accounting behavior and personnel controls. Accounting Organizations and Society, 22 (3), $233-248$.

Chenhall, R. H. (2005). Content and process approaches to studying strategy and management control systems. Controlling Strategy: Management, Accounting, and Performance Measurement. Oxford: Oxford University Press.

Dent, J. F. (1990). Strategy, organization and control: some possibilities for accounting research. Accounting, Organizations and Society, 15 (1), 3 - 25.

Flamholtz, E. G. (1983). Accounting, Budgeting and Control Systems in Their Organizational Context: Theoretical and Empirical Perspectives. Accounting, Organizations and Society, (8), 153-174.

Floyd, S. W. dan Woolridge, B. (1992). Managing strategic consensus: the foundation of effective implementation. Academy of Management Executive, 6, 27 - 39.

Heide, M., Gronhaug, K. dan Johannessen, S. (2002). Exploring barriers to the successful implementation of a formulated strategy. Scandinavian Journal of Management, 18, 217 231.

Henri, J-F. (2006). Management control systems and strategy: A resource-based perspective. Accounting, Organizations and Society, 31 (6), 529 - 558.

Hrebiniak, L. G. dan Joyce, W. F. (1985). Organizational Adaptation: Strategic Choice and Determinism. Administrative Science Quarterly, 30, 336 - 349.

Ittner, C. D. dan Larcker, D. F. (2001). Assessing empirical research in managerial accounting: a value-based management perspective. Journal of Accounting and Economics, 32, 349 - 410.

Ittner, C.D., Larcker, D.F. dan Meyer, M.W. (2003). Subjectivity and the Weighting of Performance Measures: Evidence from the Balanced Scorecard. The Accounting Review, vol. 78, (3), 725758.

Johnson, G. dan Scholes, K. (1999) Exploring Corporate Strategy: Text and cases, Pearson, Essex, UK.

Kald, M., Nilsson, F. dan Rapp, B. (2000). On strategy and management control: The importance of classifying the strategy of the business. British Journal of Management, 11, $197-212$.

Kober, R., Ng, J., Paul, B. J. (2007). The interrelationship between management control mechanisms and strategy. Management Accounting Research, 18, 425 - 452. 
Laffan, B. (1983). Policy implementation in the European community: the European social fund as a case study. Journal of Common Market Studies, 21, 389 - 408.

Langfield-Smith, K. (1997). Management control systems and strategy: a critical review. Accounting. Organizations and Society, 22 (2), $207-232$.

Merchant, K.A. dan Otley, D.T. (2006). A review of the literature on control and accountability. The handbook of management accounting research, Oxford: Elsevier Press.

Mintzberg, H. (1973) The Nature of Managerial Work. London: Prentice Hall.

Mintzberg, H. (1978). Patterns in strategy formation. Management Science, 24 (9), 934 - 948.

Mintzberg, H. (1987). Crafting strategy. Harvard Business Review, July/August, 66 - 75.

Mintzberg, H. (1990). The fall and rise of strategic planning. Harvard Business Review, January/February, 107 - 114

Mintzberg, H. (1994) The Rise and Fall of Strategic Planning. Hemel Hempstead: Prentice Hall.

Mintzberg, H. (1994). Rethinking strategic planning - Part 1: Pitfalls and Fallacies. Long Range Planning, 27 (3), 12 - 21.

Mintzberg, H. dan McHugh, A. (1985). Strategy formulation in an adhocracy. Administrative Science Quarterly, 30, 160 - 197.

Mintzberg, H. dan Waters, J.A. (1982). Tracking strategy in an entrepreneurial firm. Academy of Management Journal, XXV(3), 465 - 499.

Mintzberg, H. dan Waters, J.A. (1985). Of strategies: deliberate and emergent. Strategic Management Journal, 6 (7), $257-272$.

Noble, C.H. (1999). The Eclectic Roots of Strategy Implementation Research. Journal of Business Research, 45, 119-134.

Ouchi, W.G. (1979). A conceptual framework for the design of organisational control mechanisms. Management Science, 25 (9), 833 - 849.

Roberts, J. (1990). Strategy and Accounting in a U.K. conglomerate. Accounting, Organizations and Society, 15, (1), $107-125$.

Simons, R. (1987). Accounting control systems and business strategy: An empirical analysis. Accounting, Organizations and Society, 12 (4), 357 - 374.

Simons, R. (1990). The role of management control systems in creating competitive advantage: new perspectives. Accounting, Organizations and Society, 15 (1), 127 - 143.

Simons, R. (1991). Strategic orientation and top management attention to control systems. Strategic Management Journal, 12, 49 - 62.

Simons, R. (1994). How new top managers use control systems as levers of strategic renewal. Strategic Management Journal, 15, 169 - 189. 
Simons, R. (1995). Levers of control. Boston: Harvard University Press.

Simons, R. (2000) Performance Measurement and Control Systems for Implementing Strategy. New Jersey: Prentice Hall. 